\title{
Physiological performance of sunflower genotypes under combined salt and drought stress environment
}

\author{
Muhammad Umar, Zamin Shaheed Siddiqui* \\ Stress Physiology Lab., Department of Botany, University of Karachi, Karachi - 75270, Pakistan
}

\begin{abstract}
The physiological performance of some sunflower genotypes (S.28111, SF0049, Hysun-33, Hysun-39) under salt, drought stress separately and in combination was examined. Salt, drought and a combination of these stresses were applied to plants by gradual increments. The plants were exposed to stress for two weeks. Relative water content, osmotic potential, stomatal conductance, performance index, dark adapted quantum yield and chlorophyll contents were reduced upon salinity and drought stresses. However, when plants were subjected to a combination of these stresses, a greater reduction in all tested attributes was observed. Proline and carotenoid contents in drought stress were elevated compared to salt stress. Superoxide dismutase (SOD) and catalase (CAT) showed the highest activity in individual salt and drought stress with less accumulation of $\mathrm{H}_{2} \mathrm{O}_{2}$. Combined stress reduced the activity of antioxidant enzymes which ultimately decreased the physiological performance of sunflower plants. However, among the tested genotypes, S.28111 and SF0049 were found to be more tolerant to drought, salt and combined stress than both Hysun genotypes. The physiological performance of genotypes against salinity and drought individually and in combination is discussed in detail.
\end{abstract}

Key words: combined stress, genotypes, photosynthesis, screening, single stress, sunflower

\section{Introduction}

The sunflower (Helianthus annuus) is the most important source of edible oil and fourth largest oilseed crop in the world and its production is still expanding. It is planted over an area of 319,743 hectares producing 420,487 tons annually in Pakistan (Amanullah and Khan 2011). Sunflower is moderately tolerant to water stress, but its growth and production are limited in drought and salt stress environments (Aziz et al. 2013). The growth and yield of sunflower are adversely affected by abiotic stress and its yield is reduced up to $60 \%$ (Mazahery-Laghab et al. 2003). It was observed that the general effects of salt and drought stress on plant are restricted to separate exposure of these stresses. However, physiological assessment of sunflower genotypes in a combination of salt and drought stress is rather scarce. Further, the effect of combined stresses on sunflower genotypes and the basic physiological and biochemical mechanisms are still unclear. Therefore, it is necessary to study the physiological performance of sunflower plants in conditions of combined salt and drought stresses. Further, a selection of sunflower cultivars with better physiological responses to combined abiotic stresses would provide novel options to growers under different environmental conditions, as in nature plants are exposed to a combination of several stresses at a time.

In the last few decades drastic climatic changes have been observed, probably due to global warming, which has brought about not only a serious environmental threat but also substantial reductions in the yield and the crop quality. Plants are frequently exposed to many extremes such as drought stress, low/high temperature, salt stress, flooding stress, and heavy metal toxicity while growing in nature. Among these, drought and salinity are the major environmental constraints that lead to detrimental effects on a plant's life and hence crop productivity. About $33 \%$ of the world's arable land has to face crop reductions due to cyclic or unpredictable drought, whereas salinity, a huge and worldwide problem, has affected about one billion hectares of land (Wicke et al. 2011). Salt and drought

* Corresponding author, e-mail: zaminss@uok.edu.pk 
stresses affect many morphological features and alter the physiological processes that are associated with plant growth and development (Siddiqui et al. 2008). It was reported that in drought stress, plant growth retardation is linked with photosynthesis, respiration, and nutrient metabolism. Further, production of reactive oxygen species (ROS) in extreme environments like high salt concentration adversely affects plant growth and development (Munns and Tester 2008).

To improve agricultural productivity, it is necessary to develop resistant varieties by an understanding of the physiological and biochemical mechanisms or selecting better genotypes capable of performing well in stress conditions. It was reported that changes undergone by plants as a result of combined stresses are markedly different to responses to individual stresses (Grzesiak et al. 2016). Different plant species and even genotypes may have varying responses to salt and drought stresses. Therefore, the objectives of the present study were: 1) to assess the physiological performance of sunflower genotypes in salt and drought stresses separately or in combination, and 2) to identify a suitable genotype for a stress environment on the basis of its physiological and antioxidant performance.

In this study, physiological and biochemical parameters used in the screening of salt or drought stress were selected (Siddiqui et al. 2016) and their correlations are presented. This approach may be useful to identify physiologically tolerant genotypes of sunflower under water limited, salinity prone and combined stress environments.

\section{Materials and methods}

\section{Plant material and experimental operation}

The experiment was carried out in a greenhouse at the Department of Botany, University of Karachi, Pakistan. Plastic pots $(15 \times 18 \mathrm{~cm})$ were filled with $1.5 \mathrm{~kg}$ of air dried soil. The soil types used in this trial were sandy loam, $\mathrm{pH} 7.5$. Seeds of Helianthus annuus (sunflower cultivars: S.28111, Hysun-33, Hysun-39, and SF0049) were collected from the seed certification department of the government of Pakistan. S.28111 and SF0049 are new sunflower genotypes originated by Arysta Life Science and FMC Corporation. Physiological performance of these genotypes under stress environment was not available. However, genotypes Hysun-33 and Hysun-39 were known to moderately tolerate drought and salt without the physiological explanation for this having been reported. Seeds were surface sterilized with $2 \%$ sodium hypochlorite for five minutes. Five seeds per pot were sown and 12 days after sowing (DAS) pots were thinned to three seedlings per each pot. Salinity and drought treatments were initiated 30 DAS and lasted till about 44 DAS. Control plants were irrigated with tap water and soil was kept humid (more that $70 \%$ water holding capacity) until harvesting. For salinity, $175 \mathrm{mM} \mathrm{NaCl}$ concentration (almost $17 \mathrm{dS} \mathrm{m}^{-1}$ ) was applied in gradual increments. To achieve the desired salt concentration, aliquots of the following $\mathrm{NaCl}$ solutions were used in order: $75 \mathrm{mM}, 50 \mathrm{mM}$ and $50 \mathrm{mM}$ (Tab. 1). Later, soil was kept humid, retaining more than $70 \%$ water holding capac-
Tab. 1. Soil parameters: soil moisture contents (SMC) and electrical conductivity (EC) during gradual increment of the soil salinity/ drought treatments. Drought stress was imposed by withholding water. Parameters of the last treatment were maintained until the time of harvesting. \pm SE indicates the standard error of mean. Bold values represent the final parameters values of each treatment at the time of harvesting.

\begin{tabular}{|c|c|c|c|c|c|c|}
\hline $\begin{array}{l}\text { Stress } \\
\text { type }\end{array}$ & $\begin{array}{c}\text { Salt } \\
\text { application }\end{array}$ & $\begin{array}{l}\mathrm{NaCl} \\
(\mathrm{mM})\end{array}$ & Day & $\begin{array}{c}\text { SMC } \\
(\%)\end{array}$ & $\begin{array}{c}\text { EC } \\
\left(\mathrm{dS} \mathrm{m}^{-1}\right)\end{array}$ & $\mathrm{pH}$ \\
\hline \multirow{3}{*}{ Salinity } & $1^{\text {st }}$ & 75 & $1^{\text {st }}$ & $80-90$ & $7.4 \pm 0.08_{a}$ & 7.98 \\
\hline & $2^{\text {nd }}$ & 50 & $3^{\text {rd }}$ & $80-90$ & $12.0 \pm 0.15_{\mathrm{b}}$ & 8.04 \\
\hline & $3^{\text {rd }}$ & 50 & $5^{\text {th }}$ & 80-90 & $16.9 \pm 0.05_{c}$ & 8.09 \\
\hline \multirow{3}{*}{ Drought } & -- & -- & $2^{\text {nd }}$ & $60-65$ & $1.8 \pm 0.014$ & 8.01 \\
\hline & -- & -- & $4^{\mathrm{rd}}$ & $35-40$ & $2.0 \pm 0.013_{\mathrm{ab}}$ & 8.08 \\
\hline & -- & -- & $6^{\text {th }}$ & $20-25$ & $2.3 \pm 0.034_{b}$ & 8.13 \\
\hline \multirow{6}{*}{$\begin{array}{c}\text { Salinity } \\
+ \\
\text { drought }\end{array}$} & $1^{\text {st }}$ & 75 & $1^{\text {st }}$ & $80-90$ & $7.4 \pm 0.08_{a}$ & 8.01 \\
\hline & $2^{\text {nd }}$ & 50 & $3^{\text {rd }}$ & $80-90$ & $12.0 \pm 0.15_{\mathrm{b}}$ & 8.05 \\
\hline & $3^{\mathrm{rd}}$ & 50 & $5^{\text {th }}$ & $80-90$ & $16.9 \pm 0.05_{c}$ & 8.11 \\
\hline & -- & -- & $7^{\text {th }}$ & $60-70$ & $19.4 \pm 0.08_{\mathrm{d}}$ & 8.18 \\
\hline & -- & -- & $9^{\text {th }}$ & $40-50$ & $21.1 \pm 0.12_{\mathrm{e}}$ & 8.19 \\
\hline & -- & -- & $12^{\text {th }}$ & $20-25$ & $24.2 \pm 0.17_{f}$ & 8.24 \\
\hline
\end{tabular}

ity throughout the experimental periods (Table 1). Drought stress was imposed by withholding water until soil moisture content (SMC) reached 20\% and then maintained throughout the experiment. Combined salt and drought stress was achieved by progressive imposition of $175 \mathrm{mM} \mathrm{NaCl}$ i.e. $1^{\text {st }}$ salt application was $75 \mathrm{mM}, 2^{\text {nd }} 50 \mathrm{mM}$ and $3^{\text {rd }} 50 \mathrm{mM}$ and then withholding water until SMC fell to $20 \%$. Soil moisture, electrical conductivity and $\mathrm{pH}$ were measured using soil sensor (SDI-12 hydra probe II, Stevens water, USA) and $\mathrm{pH}$ meter (Adwa AD111, Romania), respectively (Tab. 1). The experiment was arranged in a randomized block design with four replicates for each treatment. At the end of the experiment, physiological measurements, biochemical quantification, and phenotypic characters were studied.

\section{Chlorophyll fluorescence and stomatal conductance}

The stomatal conductance $\left(\mathrm{g}_{\mathrm{s}}\right)$ and chlorophyll fluorescence were recorded on the youngest fully expanded leaf between 9:00 AM - 11:00 AM using a steady state diffusion porometer, Model SC-1 (Decagon devices) and chlorophyll fluorescence meter (OS-30p+, Opti-Science, USA) respectively. For chlorophyll fluorescence leaves were dark-adapted using clips. After half an hour of dark adaptation, the chlorophyll fluorescence parameters ratio of variable florescence to maximum florescence $\left(\mathrm{F}_{\mathrm{v}} / \mathrm{F}_{\mathrm{m}}\right)$, which reflected maximum photochemical efficiency of PS-II, and photosynthetic performance index $\left(\mathrm{PI}_{\mathrm{abs}}\right)$ were recorded (Maxwell and Johnson 2000). Afterwards, plants were harvested and biomass production, relative water content, free proline quantification, $\mathrm{H}_{2} \mathrm{O}_{2}$ content and antioxidant enzymes activity were examined.

\section{Photosynthetic pigments}

Fresh leaf samples (500 mg) were used for the extraction of pigments in $10 \mathrm{~mL}$ of $96 \%$ methanol, which was then centri- 
fuged at $4000 \mathrm{rpm}$ for $10 \mathrm{~min}$. Total chlorophyll, chlorophyll $a$, chlorophyll $b$ and carotenoid contents were determined according to Lichtenthaler (1987). The absorbance was read at 666,653 and $470 \mathrm{~nm}$ using a spectrophotometer. The amounts of these pigments were calculated and expressed in $\mu \mathrm{g} \mathrm{mg}^{-1}$ fresh weight (FW) (Lichtenthaler and Wellburn 1985):

$$
\begin{aligned}
& \mathrm{C} a=15.65 \times \mathrm{A}_{666}-7.340 \times \mathrm{A}_{653} \\
& \mathrm{C} b=27.05 \times \mathrm{A}_{653}-11.21 \times \mathrm{A}_{666} \\
& \text { Carotenoids }=\left(1000 \times \mathrm{A}_{470}-2.860 \times \mathrm{C} a-129.2 \times \mathrm{C} b\right) / 245
\end{aligned}
$$

Where $\mathrm{A}=$ absorbance, $\mathrm{C} a=$ chlorophyll $a$ content and $\mathrm{C} b=$ chlorophyll $b$ content

\section{Leaf water status}

Leaf water status was evaluated as the leaf relative water content (RWC). RWC was determined from the youngest fully expanded leaves. The leaves were weighed immediately after harvesting to obtain the fresh weight (FW). The same leaves were then subsequently rehydrated in distilled water for $4 \mathrm{~h}$ to obtain the turgid weight (TW), and finally dried for $48 \mathrm{~h}$ at $72{ }^{\circ} \mathrm{C}$ to obtain the dry weight (DW) (Barrs and Weatherley 1962). RWC was calculated by the following formula with slight modification and expressed in percent (Smart and Bingham 1974):

$$
\mathrm{RWC}=\mathrm{FW}-\mathrm{DW} / \mathrm{TW}-\mathrm{DW} \times 100
$$

\section{Osmotic potential $\left(\psi_{s}\right)$}

Three randomly selected fully developed leaves of each treatment and control were taken and frozen in liquid nitrogen to measure $\psi_{s}$. The frozen leaves were thawed at room temperature and centrifuged at 12,000 g. Finally the osmolarity of extracted sap was recorded using an osmometer type 6 (Loser Messtechnik, Berlin, Germany) and expressed in bars.

\section{Hydrogen peroxide $\left(\mathrm{H}_{2} \mathrm{O}_{2}\right)$ content}

$\mathrm{H}_{2} \mathrm{O}_{2}$ content was measured according to the procedure of Velikova et al. (2000). $100 \mathrm{mg}$ of fresh leaf samples were homogenized with $3 \mathrm{~mL}$ of $0.1 \%(\mathrm{w} / \mathrm{v})$ trichloroacetic acid and then centrifuged at $12,000 \mathrm{~g}$ for 15 minutes. Later, $0.5 \mathrm{~mL}$ of $10 \mathrm{mM}$ potassium phosphate buffer $(\mathrm{pH} \mathrm{7.0)}$ and $1 \mathrm{~mL}$ of 1 $\mathrm{M}$ potassium iodide were added to $0.5 \mathrm{~mL}$ of the supernatant. Finally, the absorbance was recorded at $390 \mathrm{~nm}$. The amount of $\mathrm{H}_{2} \mathrm{O}_{2}$ was calculated using extinction coefficient $(43.6 \mathrm{mM}$ $\mathrm{cm}^{-1}$ ) and expressed as $\mu \mathrm{mol} \mathrm{g} \mathrm{g}^{-1} \mathrm{FW}$.

\section{Proline analysis}

Proline was estimated according to the method of Bates et al. (1973). Fresh leaf samples (500 mg) were homogenized in $10 \mathrm{~mL}$ of sulphosalicylic acid $(3 \% \mathrm{w} / \mathrm{v})$ and the extract was filtered through Whatman's No. 2 filter paper. In a $2 \mathrm{~mL}$ aliquot, $2 \mathrm{~mL}$ of acid ninhydrin and $2 \mathrm{~mL}$ of glacial acetic acid were added and the contents were boiled for $1 \mathrm{~h}$ at $100^{\circ} \mathrm{C}$ in a water bath. The reaction mixture was further extracted with $2 \mathrm{~mL}$ of toluene by mixing thoroughly with vigorous stirring for 15 to $20 \mathrm{sec}$. Chromophore containing toluene was separated from the aqueous phase. Later absorbance was recorded at $520 \mathrm{~nm}$ against toluene blank. Proline content in sample was estimated by referring to a standard curve made from known concentrations of proline using the following formula: $\mu$ moles proline $\mathrm{g}^{-1} \mathrm{FW}=\{(\mu \mathrm{g}$ proline $/ \mathrm{ml} \times \mathrm{ml}$ toluene $)$ / $115.5 \mu \mathrm{g} / \mu \mathrm{mol}\} /$ (g sample) / 5

\section{Enzyme extraction}

$500 \mathrm{mg}$ of leaf samples were collected and crushed in liquid nitrogen and then homogenized at $4{ }^{\circ} \mathrm{C}$ in $10 \mathrm{~mL}$ protein extraction buffer containing $100 \mathrm{mM}$ Tris- $\mathrm{HCl}$ (pH 6.8), $50 \mathrm{mg}$ polyvinylpyrrolidone (PVP), and $0.1 \mathrm{mM}$ EDTA. The contents were centrifuged at $14095 \times$ g for 15 min using Smart R-17, Hanil centrifuge. Total protein was estimated by the method of Bradford (1976).

Catalase (CAT) activity was estimated by the method of Patterson et al. (1984). The decomposition of $\mathrm{H}_{2} \mathrm{O}_{2}$ was measured at $240 \mathrm{~nm}$ taking the optical density at $240 \mathrm{~nm}$ as 43.6 $\mathrm{mM} \mathrm{cm}^{-1}$ (extinction coefficient). Reaction mixture $(3.0 \mathrm{~mL})$ consisted of $10.5 \mathrm{mM} \mathrm{H}_{2} \mathrm{O}_{2}$ in $0.05 \mathrm{M}$ potassium phosphate buffer $(\mathrm{pH} 7.0)$ and the reaction was initiated after the addition of $0.1 \mathrm{~mL}$ enzyme extract at $25^{\circ} \mathrm{C}$. The decrease in absorbance at $240 \mathrm{~nm}$ was used to calculate the activity. One unit of CAT activity is defined as the amount of enzyme that catalyzes the conversion of $1 \mathrm{mM}$ of $\mathrm{H}_{2} \mathrm{O}_{2} \min ^{-1}$ at $25^{\circ} \mathrm{C}$.

The assay for superoxide dismutase (SOD) activity was performed by following the method of Beyer and Fridrovich (1987). The reaction mixture $(27.0 \mathrm{~mL})$ with $\mathrm{pH} 7.8$ was prepared using $23.75 \mathrm{~mL}$ of potassium phosphate buffer $(0.05$ M), $1.5 \mathrm{~mL}$ of L-methionine ( $300 \mathrm{mg}$ per $2.7 \mathrm{~mL}), 1.0 \mathrm{~mL}$ of nitroblue tertrazolium salt ( $14.4 \mathrm{mg}$ per $10 \mathrm{ml}), 0.75 \mathrm{~mL}$ of triton X-100. One mL aliquots of assay mixture were transferred into small glass tubes, followed by the $20 \mu \mathrm{L}$ enzyme extract and $10 \mu \mathrm{L}$ of riboflavin $(4.4 \mathrm{mg}$ per $100 \mathrm{~mL})$ were added. The cocktail was mixed and then illuminated for 15 minutes in an aluminum foil-lined box, containing $25 \mathrm{~W}$ fluorescent tubes. In a control tube the sample was replaced by $20 \mu \mathrm{L}$ of buffer and the absorbance was measured at $560 \mathrm{~nm}$. The reaction was stopped by switching off the light and placing the tubes in the dark. Increase in absorbance due to formation of formazan was measured at $560 \mathrm{~nm}$. Under the described conditions, the increase in absorbance in the control was taken as $100 \%$ and the enzyme activity in the samples was calculated by determining the percentage inhibition per minute. One unit of SOD is the amount of enzyme that causes a $50 \%$ inhibition of the rate for reduction of nitro blue tetrazolium salt under the conditions of the assay.

\section{Statistical analysis}

Statistical analysis of the collected data was performed using the Duncan (1955) multiple range test $(\mathrm{p} \leq 0.05)$ and Pearson's correlation with the help of the personal computer software packages IBM SPSS Statistics (version 20). To test the differences among mean values, Duncan's test was computed and the resultant values were expressed in a bar graph as alphabets. Difference in means and their F-values were calculated and are given in Table 2. 
Tab. 2. Effects of double stress on performance index $\left(\mathrm{PI}_{\mathrm{abs}}\right)$, quantum yield $\left(\mathrm{F}_{\mathrm{v}} / \mathrm{F}_{\mathrm{m}}\right.$ ratio), stomatal conductance $\left(\mathrm{g}_{\mathrm{s}}\right)$, relative water content (RWC), total chlorophyll content (T.chl), leaf area (LA), osmotic potential $\left(\psi_{s}\right)$, catalase activity $(\mathrm{CAT})$, hydrogen peroxide $\left(\mathrm{H}_{2} \mathrm{O}_{2}\right)$, photochemical quenching $(\mathrm{qP})$, carotenoids contents (Car), superoxide dismutase activity (SOD) in sunflower genotypes expressed as increment or decline percentage over control. Highest increment/decline is presented in bold. ${ }^{\star}$ denotes $\mathrm{p}$-value $<0.01$, ${ }^{* *}$ denotes $\mathrm{p}$-value $<0.001,{ }^{* * *}$ denotes $\mathrm{p}$-value $<0.0001, \mathrm{~ns}-$ not significant.

\begin{tabular}{|c|c|c|c|c|c|c|c|c|c|c|c|c|}
\hline \multicolumn{13}{|c|}{ Decline $\%(-)$} \\
\hline Genotypes & $\mathrm{PI}_{\mathrm{abs}}$ & F-value & $\mathrm{F}_{\mathrm{v}} / \mathrm{F}_{\mathrm{m}}$ & F-value & $\mathrm{g}_{\mathrm{s}}$ & F-value & RWC & F-value & T.chl & F-value & LA & F-value \\
\hline S.28111 & 31.8 & $16.4^{\star *}$ & 10.6 & $20.5^{\star * *}$ & 80.4 & $225^{* * *}$ & 44.9 & $42.8^{\star * *}$ & 12.4 & $20.2^{\star * *}$ & 58.4 & $188^{* * *}$ \\
\hline Hysun-33 & 52.1 & $20.6^{* *}$ & 21.0 & $35.2^{* * *}$ & 75.0 & $110^{* *}$ & 55.6 & $30.9^{* *}$ & 63.1 & $1169^{*}$ & 59.2 & $202^{* * *}$ \\
\hline Hysun-39 & 32.8 & $14.3^{* *}$ & 13.8 & $40.2^{* * *}$ & 76.9 & $252^{\star}$ & 49.6 & $125^{* * *}$ & 32.8 & $58.0^{* * *}$ & 67.4 & $74.4^{* * *}$ \\
\hline SF0049 & 21.8 & $11.6^{*}$ & 07.4 & $15.7^{\star *}$ & 77.8 & $452^{\star * *}$ & 37.2 & $13^{* *}$ & 31.1 & $32.7^{* * *}$ & 54.4 & $239^{* * *}$ \\
\hline \multicolumn{13}{|c|}{ Increment \% (+) } \\
\hline Genotypes & $\psi_{s}$ & F-value & CAT & F-value & $\mathrm{H}_{2} \mathrm{O}_{2}$ & F-value & $\mathrm{qP}$ & F-value & Car & F-value & SOD & F-value \\
\hline S.28111 & 81.8 & $393^{* *}$ & 50 & $38.4^{* \star *}$ & 43.2 & $109^{* *}$ & 80.4 & $1.43^{\mathrm{ns}}$ & 10.6 & $149^{\star * *}$ & 20.4 & $26.3^{* * *}$ \\
\hline Hysun-33 & 70.5 & $171^{\star * *}$ & 25 & $13.2^{\star *}$ & 48.9 & $83.8^{\star * *}$ & 75.6 & $15.8^{\star *}$ & 22.9 & $70.2^{\star * *}$ & 26.6 & $21.7^{* * *}$ \\
\hline Hysun-39 & 70.9 & $112^{* \star}$ & 40.3 & $25.0^{\star \star \star}$ & 49.2 & $57.9^{\star * *}$ & 79.4 & $0.33^{\mathrm{ns}}$ & 06.4 & $40.5^{\star}$ & 21.2 & $18.5^{\star}$ \\
\hline SF0049 & 81.9 & $210^{* * *}$ & 45 & $20.7^{\star * *}$ & 44.6 & $99.5^{\star \star}$ & 34.1 & $5.88^{\star}$ & 20.2 & $19.6^{* *}$ & 17.1 & $18.8^{\star \star}$ \\
\hline
\end{tabular}

\section{Results}

The application of single stress (drought and salt separately) and combined stress showed significant reduction in biomass production of each tested sunflower genotype. Relative water content was substantially decreased in all treated genotypes under single and combined stress environment (Fig. 1). However, in combined stress, 45, 56, 49 and 37\% reduction were observed in S.28111, Husun-33, Hysun-39 and SF0049, respectively (Tab. 2). Leaf area of each plant was decreased in all treatments compared to control. Reduction in leaf area was recorded up to 58,59,67 and 51\% under combined stress in S.28111, Hysun-33, Hysun-39 SF0049, respectively (Tab. 2). Reduction in leaf number was the highest in Hysun-33, whereas the lowest reduction was observed in SF0049 (Fig. 1). Salt and drought stress significantly reduced the height of all sunflower genotypes in comparison to corresponding controls. It was observed that S.28111 is the least affected among the genotypes (Fig. 1). Higher reduction in shoot height was observed in Hysun-33 and Hysun-39, of about 42 and 38\% as compared to their controls, respectively. Free proline production was significantly affected in the tested sunflower genotypes. It was observed that proline concentrations were higher in combined stress as compared to drought or salt stress (Fig. 1). The order of proline accumulation in genotypes under combined stress varied for instance from the maximum in Hysun-39>Hysun-33>S.28111>SF0049 (minimum).

Sunflower genotypes exhibited a substantial decrease in $\mathrm{PI}_{\mathrm{abs}}$ in all stresses as compared to control. Combined stress significantly reduced the $\mathrm{PI}_{\mathrm{abs}}$ in all the genotypes as compared to control and individual stresses (Fig. 2). However, the highest decreased in $\mathrm{PI}_{\mathrm{abs}}$ was shown in Hysun-33 under

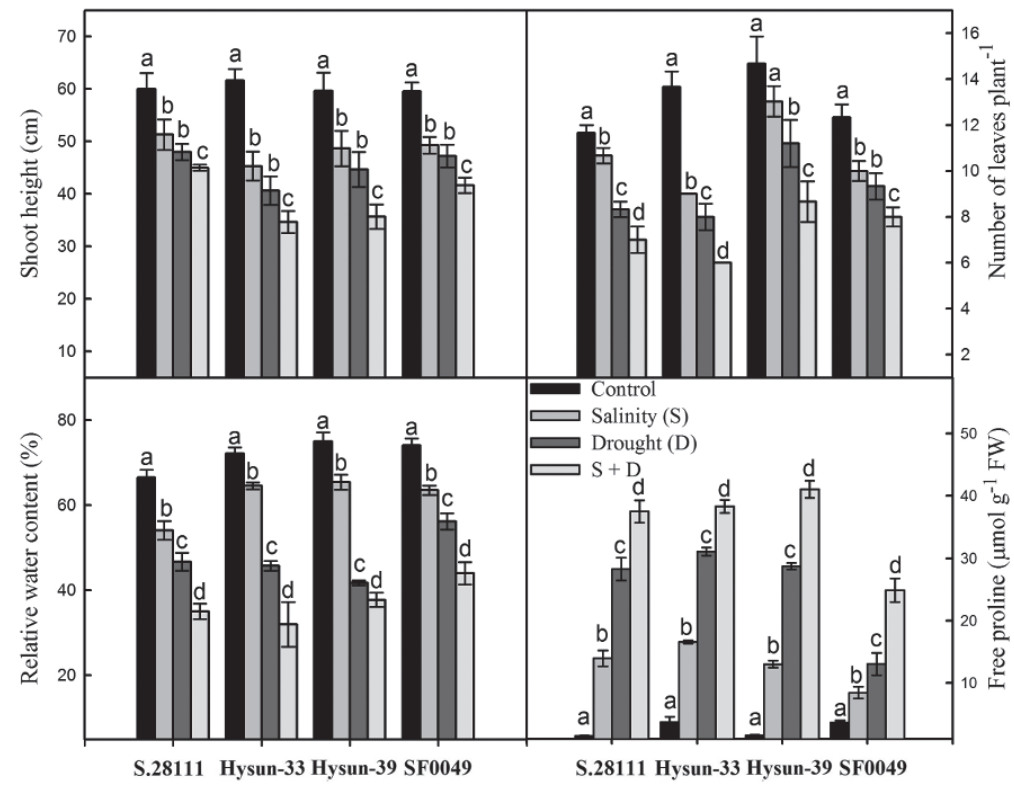

Fig. 1. Effects of salt (S), drought (D) and combined (S + D) stress on shoot height, number of leaves, relative water content and free proline content of sunflower genotypes. Bar represents mean \pm SE $(n=4)$. Same letter above the bars denotes that among each genotype the difference between means is not significant at $\mathrm{p}=0.05$. 


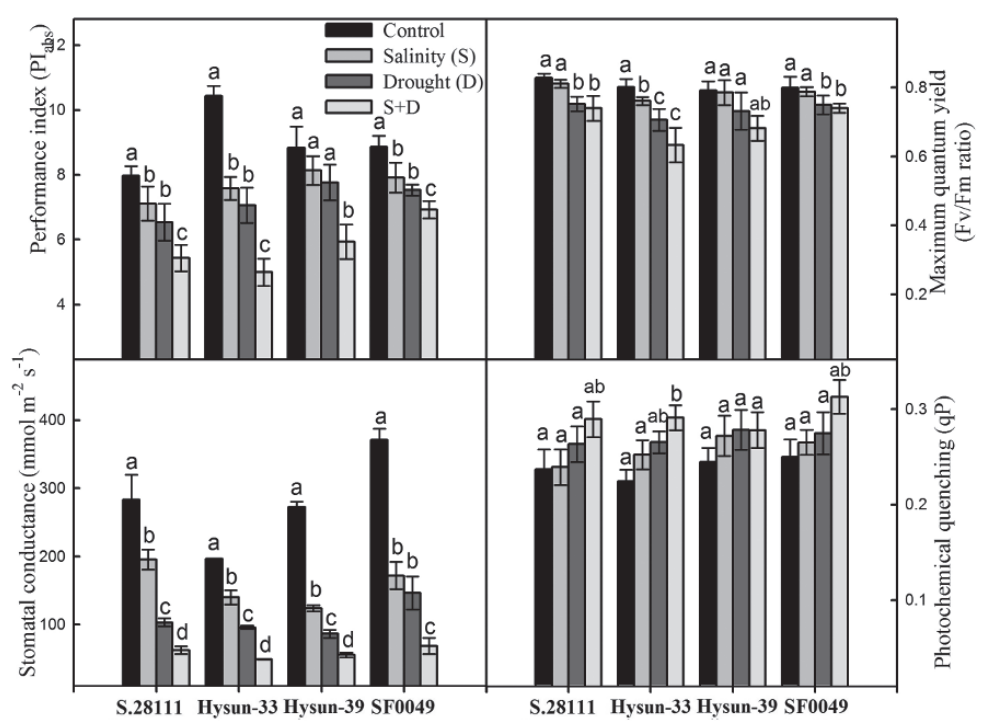

Fig. 2. Effects of salt, drought and combined $(S+D)$ stress on $F_{v} / F_{m}$ ratio, $P_{a b s}, q P$ and $g_{s}$ of sunflower genotypes. Values are mean $\pm S E$ $(\mathrm{n}=4)$. Same letter above the bars denotes that among each genotype the difference between means is not significant at $\mathrm{p}=0.05$.

combined stress. A marginal decline was detected in maximum photochemical efficiency of photosystem II $\left(\mathrm{F}_{\mathrm{v}} / \mathrm{F}_{\mathrm{m}}\right.$ ratio) when sunflower plants were treated alone with salt and drought stress. A significant reduction was observed in $\mathrm{F}_{\mathrm{v}} / \mathrm{F}_{\mathrm{m}}$ ratio under combined stress, of $21 \%$ in Hysun- 33 whereas only a $7.4 \%$ reduction was found in SF0049. In both individual and combined stresses photochemical quenching $(\mathrm{qP})$ was not significantly affected. The stomatal conductance of each genotype was reduced by the salt and drought stress (Fig. 2). The stomatal conductance under salt and drought stress was higher in SF0049 than in the other genotypes. It was observed that both Hysun genotypes had the lowest stomatal conductance in the individual stress conditions (Fig. 2).

The plants showed a substantial reduction in total chlorophyll content in stress environments (Fig. 3). Greater reduc- tion was found in Husun-33 in combined stress conditions than in the other genotypes. The total carotenoid concentration was increased in stressful environment when genotypes were treated with single or combined stresses. The highest carotenoid concentration was shown in Hysun-33 under combined stress whereas the lowest concentration was recorded in S.28111.

Osmotic potential $\left(\psi_{s}\right)$ of each genotype decreased in drought and salt stressed plants as compared to unstressed (control) plants. A greater decline in osmotic potential was observed during combined stresses (Fig. 4). Antioxidant enzymes like SOD and CAT were examined in genotypes when plants were exposed to a single (drought/salt) and to combined (salt + drought) stresses. Plants treated with drought, salinity or in combination, showed significant increases in SOD and CAT as compared to control. It was observed that

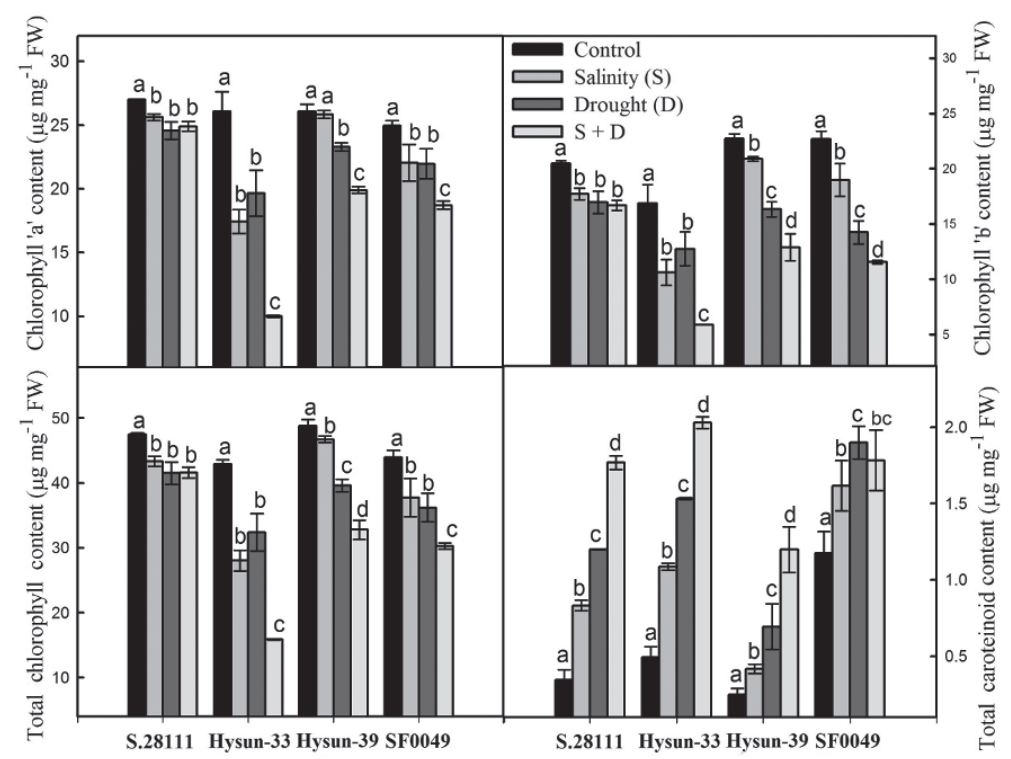

Fig. 3. Effects of salt, drought and combined $(S+D)$ stress on contents of photosynthetic pigments of sunflower genotypes. Values are mean $\pm \operatorname{SE}(n=4)$. Same letter above the bars denotes that among each genotype the difference between means is not significant at $\mathrm{p}=0.05$. 


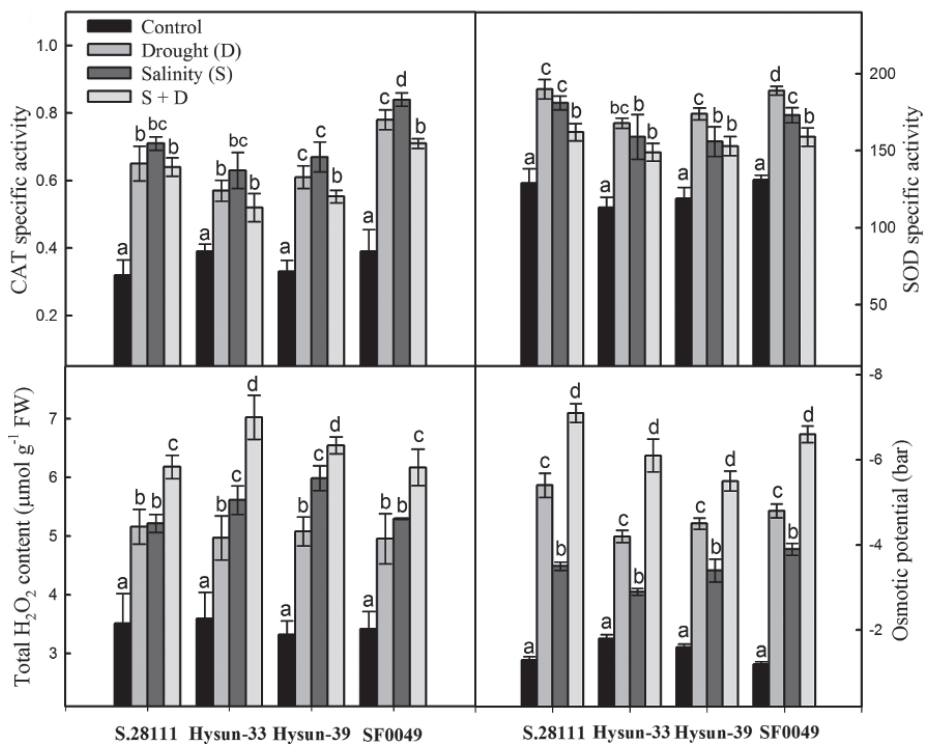

Fig. 4. Effects of salt, drought and combined $(\mathrm{S}+\mathrm{D})$ stress on activity of antioxidant enzymes CAT and SOD (expressed as unites mg-1 proteins), $\mathrm{H}_{2} \mathrm{O}_{2}$ content and osmotic potential of sunflower genotypes. Values are mean $\pm \mathrm{SE}(\mathrm{n}=4)$. Same letter above the bars denotes that among each genotype the difference between means is not significant at $\mathrm{p}=0.05$.

CAT and SOD activities were increased in all genotypes under single stress as compared to control (Fig. 5). More antioxidant activities were observed in S.28111 and SF0049 than in Hysun-33 and Hysun-39; however, SOD activity did not significantly differ in single stresses, drought or salinity. $\mathrm{H}_{2} \mathrm{O}_{2}$ is a known stress indicator in plants and its concentration increases in abiotic stress. The data showed that the concentration of $\mathrm{H}_{2} \mathrm{O}_{2}$ increased in all genotypes under both drought and salt stress. However, $\mathrm{H}_{2} \mathrm{O}_{2}$ contents increased much more under drought stress than under salt stress, concentrations getting higher still under combined stress. It was observed that production of $\mathrm{H}_{2} \mathrm{O}_{2}$ contents were reduced in S.28111 and SF0049 more than in other genotypes. Table 2 showed that both Hysun genotypes had the highest decline in RWC, leaf area, total chlorophyll and $\mathrm{PI}_{\mathrm{abs}}$ under combined stress compared to their control, whereas S.28111 and SF0049 had the highest osmotic potential and CAT activity.
The outcome of correlation analysis is given in Table 3 . Proline, carotenoids and $\mathrm{H}_{2} \mathrm{O}_{2}$ are negatively correlated with all the parameters and are positive with each other. Catalase activity was negatively correlated with $\mathrm{PI}_{\mathrm{abs}}, \mathrm{F}_{\mathrm{v}} / \mathrm{F}_{\mathrm{m}}$ ratio, RWC, $\mathrm{g}_{\mathrm{s}}$, and chlorophyll content. The correlation of CAT is found to be significant with gs, carotenoid, $\mathrm{H}_{2} \mathrm{O}_{2}, \psi_{s}$ and SOD. $\mathrm{PI}_{\text {abs }}$ significantly correlated with SOD and non-significantly with CAT whereas $g_{s}$ was non-significantly correlated with CAT and significantly with SOD.

\section{Discussion}

Reduction in plant biomass in response to drought and salt stress is a common phenomenon. Substantial reductions in number of leaves and height of plants were recorded in Hysun-33 and Hysun-39, more so than in S.28111 and SF0049. RWC of each sunflower genotype was reduced in both single

Tab. 3. Pearson correlation among performance index $\left(\mathrm{PI}_{\mathrm{abs}}\right)$, maximum quantum yield $\left(\mathrm{F}_{\mathrm{v}} / \mathrm{F}_{\mathrm{m}}\right.$ ratio), relative water contents (RWC), stomatal conductance $\left(\mathrm{g}_{\mathrm{s}}\right)$, leaf area (LA), total chlorophyll content (T.chl), carotenoids content (Car), proline, hydrogen peroxide $\left(\mathrm{H}_{2} \mathrm{O}_{2}\right)$, osmotic potential $\left(\psi_{s}\right)$, and superoxide dismutase (SOD). ${ }^{*}$ denotes $\mathrm{p}<0.01$ (2-tailed), ${ }^{\star}$ denotes $\mathrm{p}<0.05$ level (2-tailed), ns - not significant.

\begin{tabular}{|c|c|c|c|c|c|c|c|c|c|c|c|c|}
\hline & $\mathrm{PI}_{\text {abs }}$ & FvFm & RWC & gs & LA & T.chl & Car & Proline & $\mathrm{H}_{2} \mathrm{O}_{2}$ & $\psi s$ & SOD & CAT \\
\hline $\mathrm{PI}_{\mathrm{abs}}$ & 1 & $.735^{* *}$ & $.886^{* *}$ & $.700^{* *}$ & $.742^{* *}$ & $.594^{*}$ & $-.654^{* *}$ & $-.836^{* *}$ & $-.847^{* *}$ & $.763^{* *}$ & $-.520^{*}$ & $-.413^{\mathrm{ns}}$ \\
\hline $\mathrm{F}_{\mathrm{v}} / \mathrm{F}_{\mathrm{m}}$ & & 1 & $.820^{* *}$ & $.748^{* *}$ & $.830^{* *}$ & $.822^{* *}$ & $-.630^{* *}$ & $-.890^{* *}$ & $-.840^{* *}$ & $.529^{*}$ & $-.160^{\mathrm{ns}}$ & $-.279^{\mathrm{ns}}$ \\
\hline RWC & & & 1 & $.841^{* *}$ & $.857^{* *}$ & $.599^{*}$ & $-.606^{*}$ & $-.942^{* *}$ & $-.929^{* *}$ & $.718^{* *}$ & $-.395^{\mathrm{ns}}$ & $-.465^{\mathrm{ns}}$ \\
\hline$g_{s}$ & & & & 1 & $.920^{* *}$ & $.598^{*}$ & $-.516^{*}$ & $-.850^{* *}$ & $-.910^{* *}$ & $.777^{\star *}$ & $-.474^{\mathrm{ns}}$ & $-.611^{*}$ \\
\hline LA & & & & & 1 & $.609^{*}$ & $-.583^{*}$ & $-.918^{* *}$ & $-.912^{* *}$ & $.712^{* *}$ & $-.441^{\mathrm{ns}}$ & $-.589^{*}$ \\
\hline T-Chl & & & & & & 1 & $-.715^{\star *}$ & $-.640^{* *}$ & $-.712^{* *}$ & $.529^{*}$ & $-.224^{\mathrm{ns}}$ & $-.297^{\mathrm{ns}}$ \\
\hline Car & & & & & & & 1 & $.551^{*}$ & $.666^{* *}$ & $-.627^{* *}$ & $.413^{\mathrm{ns}}$ & $.612^{*}$ \\
\hline Proline & & & & & & & & 1 & $.918^{* *}$ & $-.673^{* *}$ & $.340^{\mathrm{ns}}$ & $.391^{\mathrm{ns}}$ \\
\hline $\mathrm{H}_{2} \mathrm{O}_{2}$ & & & & & & & & & 1 & $-.846^{* *}$ & $.533^{*}$ & $.611^{*}$ \\
\hline$\psi_{s}$ & & & & & & & & & & 1 & $-.629^{*}$ & $-.604^{*}$ \\
\hline SOD & & & & & & & & & & & 1 & $.830^{* *}$ \\
\hline CAT & & & & & & & & & & & & 1 \\
\hline
\end{tabular}


stress and combined stress. However, maximum reduction was observed in Hysun-33 and minimum reduction found in SF0049 and S.28111. RWC is a better indicator of leaf water status and is successfully used to determine stress resistance or tolerance in many crop plants (Siddiqui et al. 2014). Many reports reveal that RWC is reduced under drought and salinity (Masoumi et al. 2010) but those plants that maintain high RWC under extreme stress are supposed to be more stress tolerant. Hence it is assumed that sunflower genotypes SF0049 and S.28111, which maintained substantial water in leaf under combined stress, could be more stress tolerant than other genotypes. It is suggested that reduced shoot height, leaf area and number of leaves in sensitive genotypes may be due to their leaves having less RWC. The accumulation of proline in a single stress and a combined stress environment was observed. S.28111 accumulated a sufficient amount of proline under a combined stress environment. The accumulation of compatible osmolytes such as proline has been regarded as a basic strategy for the protection and survival of plants under abiotic stress (Alia et al. 2001). The better plant height, number of leaves, leaf area and RWC in S.28111 under combined stress could be due to the higher accumulation of proline. Relative water content and proline content are negatively correlated ( $r=-0.942$, Table 3$)$. Therefore, it may be suggested that an increase in proline concentration might be due to the reduction in RWC under osmotic stress, indicating that synthesis of proline became higher as soon as RWC declined.

Results show that Hysun-33 had the highest decline in $\mathrm{F}_{\mathrm{v}} / \mathrm{F}_{\mathrm{m}}(21 \%)$ and $\mathrm{PI}_{\mathrm{abs}}(53 \%)$ of all the genotypes, while SF 0049 showed better results having $7.4 \%$ decline in $\mathrm{F}_{\mathrm{v}} / \mathrm{F}_{\mathrm{m}}$ ratio and $31 \%$ in $\mathrm{PI}_{\mathrm{abs}}$ in a single stressor in a combination (Tab. 2). Chlorophyll fluorescence is a sensitive indicator that often fluctuates in stress environments (Weng et al. 2008). In stress sensitive plants, $\mathrm{F}_{\mathrm{v}} / \mathrm{F}_{\mathrm{m}}$ ratio decreases under limited water conditions indicating chronic photo-inhibition (Zlatev 2009). The vitality of the plant could be characterized by the $\mathrm{PI}_{\mathrm{abs}}$, which is more sensitive to abiotic stresses (Oukarroum et al. 2007). Combined stress significantly reduced the $\mathrm{PI}_{\mathrm{abs}}$ in all the genotypes as compared to control and single stresses. However, the highest decrease in $\mathrm{PI}_{\mathrm{abs}}$ was shown in Hysun-33 under combined stress reflecting poor functionality of both PSI and PSII under stress (Strasser et al. 2004). A very small decline was observed in SF0049 under S + D as compared to control indicating better performance under stress. The $\mathrm{PI}_{\mathrm{abs}}$ showed significant correlation with all the tested parameters except catalase. RWC were highly correlated with $\mathrm{PI}_{\text {abs }}$ (0.886). This correlation showed that the reduction in performance index might be due to the decreased RWC. The stomatal conductance of each sunflower genotype was reduced by the salt and drought stress. The maximum reduction in stomatal conductance was observed in S.28111 and SF0049 under combined stress.

During salt and drought stress, less water is available for the plants to facilitate their metabolism smoothly. In osmotic stress, an imbalance between water uptake by roots and water loss by transpiration causes the plant to wilt (Lafitte 2002). Therefore, water use efficiency may be an important strategy to increase fitness under osmotic stress environment. Reports have shown that in some stress tolerant genotypes $\mathrm{ABA}$ is synthesized and accumulated which leads to stomatal closure thus avoiding unnecessary transpiration to maintain substantial cellular osmotic potential. Drought tolerant plants maximize fitness by decreasing stomatal conductance in response to the shortage of water (Ares et al. 2000). The genotypes S.28111 and SF0049 showed 80 and 78\% decline in stomatal conductance under combined stress compared to control, respectively (Tab. 2). It is suggested that these two genotypes tolerate salt and drought by decreasing stomatal conductance and thereby increasing water use efficiency. Levels of plant sensitivity, tolerance, and response timing against water stress fluctuate among genotypes / species. For example, slow-growing plant species have been found to be more sensitive than fast-growing species (Munns 2002). It was observed that tolerant plants adapt two different strategies during abiotic stress: long-living annuals and perennials decrease their leaf size and/or stomatal conductance (Siddiqui et al. 2014), while shorter-living annuals maximize fitness by increasing stomatal conductance (lessening water-use efficiency) to increase carbon gain and avoid stress. This tactic lets them grow speedily, flower early and increase yield before the start of substantial soil drying (McKay et al. 2003). Thus, it is thought genotypes S.28111 and SF0049 might adopt the early developmental strategy and enhance stress tolerance whereas both Hysun genotypes adopt the late developmental strategy and thereby have less tolerance to salt, drought and combined stress.

Genotype S.28111 showed the highest chlorophyll contents in a combined stress environment of all the tested genotypes. Further, abiotic stress causes ROS production that damages the chloroplast and as a result a reduction in chlorophyll contents occur (Smirnoff 1995). Reduction in chlorophyll under drought and salinity stresses has been reported in many plant species including sunflower (Manivannan et al. 2007). Higher reduction in chlorophyll contents in Hysun genotypes might be due to imbalance in ROS production and scavenging mechanism. The non-enzymatic antioxidants like carotenoids and proline contents were negatively correlated with photosynthetic parameters and their correlation with $\mathrm{PI}_{\mathrm{ab}}, \mathrm{F}_{\mathrm{v}} / \mathrm{F}_{\mathrm{m}}$ and total chlorophyll were highly significant. This negative correlation might be due to the protective strategy of plants under harmful environmental conditions in which chlorophyll contents are reduced and carotenoids increased.

Sunflower plants treated with drought and salinity singly or in combination, showed a significant increase in SOD and CAT compared to control. It was observed that CAT and SOD activities were increased under stresses compared to control but combined stress reduced the activity of both enzymes in all the genotypes. However, more antioxidant activities were observed in S.28111 and SF0049 than in Hysun-33 and Hysun-39. It has been reported that plant tolerance can be maintained by controlling the ROS production through non-enzymatic mechanisms, including carotenoids, proline and phenolic compounds (Jaleel et al. 2009) or to prevent plants from oxidative damage by antioxidant enzymes 
activity like CAT and SOD (Quan et al. 2008). The present study showed that CAT and SOD activities of sunflower genotypes were negatively correlated with $\mathrm{H}_{2} \mathrm{O}_{2}$ concentrations. It is presumed that the lower $\mathrm{H}_{2} \mathrm{O}_{2}$ production in drought stress may be due to enzyme activities or it may be related to higher carotenoid synthesis, which may lower $\mathrm{H}_{2} \mathrm{O}_{2}$ production in chloroplasts, thus avoiding oxidative damages. CAT is one of the enzymes that detoxify $\mathrm{H}_{2} \mathrm{O}_{2}$ in plants and it is mostly located in peroxisomes. CAT use $\mathrm{H}_{2} \mathrm{O}_{2}$ as a substrate and changes it to $\mathrm{H}_{2} \mathrm{O}$ and $\mathrm{O}_{2}$ as products.

It is clear that S.28111 and SF0049 genotypes showed better photosynthetic performance than the other genotypes under combined stress (Tab. 2). Both genotypes showed minimum decline in $\mathrm{F}_{\mathrm{v}} / \mathrm{F}_{\mathrm{m}}$ ratio, performance index and total chlorophyll. This minimum decrease under combined stress environment showed that S.28111 and SF0049 showed better physiological performance than either of the Hysun genotypes. The maximum increment in $\psi_{s}$ and CAT activity and minimum increment in $\mathrm{H}_{2} \mathrm{O}_{2}$ contents also showed that S.28111 and SF0049 have better tolerance than the Hysun genotypes in individual and combined stress. The parameters used in this trial are significantly correlated (Tab. 3). Despite combined salt and drought stress these parameters are useful to identify genotypes tolerant to water-limited and salinity-prone environments.

The present study has shown that S.28111 and SF0049 exhibited a greater degree of tolerance than the Hysuns in terms of better physiological performance against salinity,

\section{References}

Alia, J. M., Mohanty, P., Matysik, J., 2001: Effect of proline on the production of singlet oxygen. Amino Acids 21, 195-200.

Amanullah, Khan M. W., 2011: Interactive effect of potassium and phosphorus on grain quality and profitability of sunflower in northwest Pakistan. Pedosphere 21, 532-538.

Ares, A., Fownes, J. H, Sun, W., 2000: Genetic differentiation of intrinsic water-use efficiency in the Hawaiian native Acacia koa. International Journal of Plant Sciences 161, 909-915.

Aziz, R., Shahbaz, M., Ashraf, M., 2013: Influence of foliar application of triacontanol on growth attributes, gas exchange and chlorophyll fluorescence in sunflower (Helianthus annuus L.) under saline stress. Pakistan Journal of Botany 45, 1913-1918.

Barrs, H. D., Weatherley, P. E., 1962: A re-examination of the relative turgidity technique for estimating water deficits in leaves. Australian Journal of Biological Sciences 15, 413-428.

Bates, L. S., Waldren, R.P., Teare, L. D., 1973: Rapid determination of free proline water stress studies. Plant and Soil 39, 205-207.

Beyer, W. F., Fridovich, I., 1987: Assaying for superoxide dismutase activity: some large consequences of minor changes in condition. Analytical Biochemistry 161, 559-566.

Bradford, M. M., 1976: A rapid and sensitive method for the quantitation of microgram quantities of protein utilizing the principle of protein-dye binding. Analytical Biochemistry 72, 248-254.

Duncan, D. B., 1955: Multiple range and Multiple F-test. Biometrics $11,1-42$.

Grzesiak, T. M., Janowiak, F., Szczyrek, P., Kaczanowska, K., Ostrowska, A., Rut, G., Hura, T., Rzepka, A., Grzesiak, S., 2016: Impact of soil compaction stress combined with drought or water logging on physiological and biochemical markers in two maize hybrids. Acta Physiologiae Plantarum 38, 109. drought and their combination. This might be due to their early development strategy, as compared to both Hysun genotypes. It was based on the evaluation of genotypes responding to stress tolerance, which is shown as percentage increase $(+)$ /decrease (-) over control and illustrated in Table 2. The genotypes S.28111 and SF0049 showed the lowest decline in $\mathrm{PI}_{\mathrm{abs}}, \mathrm{F}_{\mathrm{v}} / \mathrm{F}_{\mathrm{m}}$ ratio, RWC and chlorophyll content. However, in all treatments the highest increase in osmotic potential, proline contents, qP, carotenoids contents and antioxidant enzymes activities was recorded. Results of the present investigation showed that SF0049 and S.28111 genotypes have better tolerance than either of the Hysun genotypes. Genotypes S.28111 and SF0049 not only showed better photosynthetic performance but also reduced the concentration of $\mathrm{H}_{2} \mathrm{O}_{2}$ in all stresses. Therefore, it may be suggested that genotypes S.28111 and SF0049 could be used in field trials for a more comprehensive study. However, more detailed molecular work is needed to provide more convincing arguments.

\section{Acknowledgements}

We are grateful to the department of Botany of the University of Karachi for supporting the study and the seed manager of FMC Corporation (Pakistan), and Seed Certification Department of Pakistan for providing seeds. The authors also acknowledge financial support from NCGC South Korea.

Jaleel, C. A., Manivannan, P., Wahid, A., Farooq, M., Al-Juburi, H. J., Somasundaram, R., Panneerselvam, R., 2009: Drought stress in plants: a review on morphological characteristics and pigments composition. International Journal of Agriculture and Biology 11, 100-105.

Lafitte, R., 2002: Relationship between leaf relative water content during reproductive stage water deficit and grain formation in rice. Field Crops Research 76, 165-174.

Lichtenthaler, H. K., 1987: Chlorophylls and carotenoids: pigments of photosynthetic membranes. Methods in Enzymology $148,350-382$.

Lichtenthaler, H. K., Wellburn, A. R., 1985: Determination of total carotenoids and chlorophylls a and $\mathrm{b}$ of leaf in different solvents. Biochemical Society Transactions 11, 591-592.

Manivannan, P., Abdul Jaleel, C., Sankar, B., Kishorekumar, A., Somasundaram, R., Lakshmanan, G. M. A., Panneerselvam, R., 2007: Growth, biochemical modifications and proline metabolism in Helianthus annuus L. as induced by drought stress. Colloids and Surfaces B: Biointerfaces 59, 141-149.

Masoumi, A., Kafi, M., Khazaei, H., Davari, K., 2010: Effect of drought stress on water status, elecrolyte leakage and enzymatic antioxidants of kochia (Kochia scoparia) under saline condition. Pakistan Journal of Botany 42, 3517-3524.

Maxwell, K., Johnson, G., 2000: Chlorophyll fluorescence - a practical guide. Journal of Experimental Botany 51, 659-668.

Mazahery-Laghab, H., Nouri, F., Abianeh, H. Z., 2003: Effects of the reduction of drought stress using supplementary irrigation for sunflower (Helianthus annuus) in dry farming conditions. Pajouheshva-Sazandegi, Agronomy and Horticulture 59, 81-86.

Mckay, J. K., Richards, J. H., Mitchell-Olds, T., 2003: Genetics of drought adaptation in Arabidopsis thaliana. I. Pleiotropy con- 
tributes to genetic correlations among ecological traits. Molecular Ecology 12, 1137-1151.

Munns, R., 2002: Comparative physiology of salt and water stress. Plant Cell and Environment 25, 239-250.

Munns, R., Tester, M., 2008: Mechanisms of salinity tolerance. Annual Review of Plant Biology 59, 651-681.

Oukarroum, A., El-Madidi, S., Schansker, G., Strasser, R. J., 2007: Probing the responses of barley cultivars (Hordeum vulgare L.) by chlorophyll fluorescence OLKJIP under drought stress and rewatering. Environmental and Experimental Botany 60, 438-446.

Patterson, B., Macrae, E., Ferguson, I., 1984: Estimation of hydrogen peroxide in plant extracts using titanium (IV). Annals of Clinical Biochemistry 139, 487-492.

Quan, L., Zhang, B., Shi, W., Li, H., 2008: Hydrogen peroxide in plants: a versatile molecule of the reactive oxygen species network. Journal of Integrative Plant Biology 50, 2-18.

Siddiqui, Z. S., Cho, J. 1., Park, S. H., Kwon, T. R., Ahn B. O., Lee, K. S., Jeong, M. J., Kim, K. W., Lee S. K., Park S. C., 2014: Physiological mechanism of drought tolerance in transgenic rice plants expressing Capsicum annuum Methionine sulfoxide reductase B2 (CaMsrB2) gene. Acta Physiologiae Plantarum 36, 1143-1153.

Siddiqui, Z. S., Khan, M. A., Kim, B. G., Huang, J.S., Kwon, T. R., 2008: Physiological responses of Brassica napus genotypes to combined drought and salt stress. Plant Stress, Global Science Books.
Siddiqui, ZS., Shahid, H., Cho, J. I., Park, S. H., Ryu, T. H., Park, S. C., 2016: Physiological responses of two halophytic grass species under drought stress environment. Acta Botanica Croatica $75,31-38$.

Smart, R. E., Bingham, G. E., 1974: Rapid estimates of relative water content. Plant Physiology 53, 258-260.

Smirnoff, N., 1995: Antioxidant systems and plant response to the environment. In: Smirnoff, N. (ed.), Environment and plant metabolism: flexibility and acclimation, 217-243. Bios Scientific Oxford.

Strasser, R. J., Tsimilli-Michael, M., Srivastava, A., 2004: Analysis of the fluorescence transient. In: George C., Papageorgiou C., Govindjee (eds.), Chlorophyll fluorescence: a signature of photosynthesis, 321-362. Advances in Photosynthesis and Respiration Series. Springer, Dordrecht.

Velikova, V., Yordanov, I., Edreva, A., 2000: Oxidative stress and some antioxidant system in acid rain-treated bean plants. Protective role of exogenous polyamines. Plant Science 151, 59-66.

Weng, X. Y., XU, H. X., Yang, Y., Peng, H. H., 2008: Water-water cycle involved in dissipation of excess photon energy in phosphorus deficient rice leaves. Biologia Plantarum 52, 307-313.

Wicke, B., Smeets, E., Dornburg, V., Vashev, B., Gaiser, T., Turkenburg, W., Faaij, A., 2011: The global technical and economic potential of bioenergy from salt-affected soils. Energy and Environmental Science 4, 2669-2681.

Zlatev, Z., 2009: Drought-induced changes in chlorophyll fluorescence of young wheat plants. Biotechnology \& Biotechnological Equipment. 23/2009/SE. 